\title{
46. Sympozjum Wykładowców Liturgiki na Wydziałach Teologicznych i w Wyższych Seminariach Duchownych (Katowice, 7-9 września 2010)
}

W dniach 7-9 września 2010 roku odbyło się w Katowicach sympozjum wykładowców liturgiki pt. Ordinatio presbyterorum. Liturgia, teologia, ministerium (do Soboru Trydenckiego). Obrady miały miejsce w auli Wydziału Teologicznego na Uniwersytecie Śląskim. Zebranych przywitali: abp Damian Zimoń, ordynariusz katowicki, ks. dr Jerzy Paliński, rektor Wyższego Seminarium Duchownego w Katowicach, ks. dr hab. Czesław Krakowiak, prof. KUL, przewodniczący Sekcji Liturgistów Polskich, i gospodarz ks. dr hab. Andrzej Żądło, prof. UŚ, dziekan Wydziału Teologicznego.

Sesję popołudniową pierwszego dnia prowadził ks. prof. dr hab. Helmut Sobeczko (Uniwersytet Opolski). Pierwszym referentem był ks. dr Dariusz Kwiatkowski (Kalisz), który przedstawił Ordinatio presbyterorum do X wieku. Swoją wypowiedź zawarł w następujących punktach: posługi i charyzmaty w Nowym Testamencie, Tradycja Apostolska Hipolita, Sakramentarz z Werony, Sakramentarz Gregoriański (typu Hadrianum), Sakramentarz Gelazjański, Ordo Romanus XXXIV-XL. W konkluzji stwierdził, że w pierwszym tysiącleciu Kościół w Rzymie wypracował rytuał udzielania święceń prezbiteratu, którego punktami zasadniczymi były: orzeczenie, że kandydat nie ma przeszkód, prezentacja kandydata, udzielenie święceń w sobotę (Quattro tempora), nałożenie rąk, modlitwa, namaszczenie rąk, pocałunek pokoju, proklamacja Ewangelii; nowo wyświęcony wchodził w ordo presbyterorum. Referent podkreślił również, że pod koniec pierwszego tysiąclecia zanika kolegialność prezbiterów, podkreślona zostaje godność z racji przyjętych święceń, a mniej mówi się o służbie.

Kolejnym prelegentem byłks. dr hab. Kazimierz Lijka OMI (Uniwersytet im. Adama Mickiewicza) prezentujący temat Ordinatio presbyterorum do Pontificale Romanum 1596. Zanalizował on: Ordines Romani XXXIV, XXXV, XXXVI i XXXIX, Pontyfikał rzymsko-germański, Pontyfikał z XII wieku, Pontyfikał Kurii Rzymskiej z XIII wieku; Pontyfikał Duranda z Mende, Pontificalis Liber z 1485 roku. Wyakcentował nowe elementy włączone do rytuału: kandydaci przygotowują się do święceń przez post, niosą świece i są ubrani jak diakoni, namaszczenie dokonuje się przy użyciu oleju katechumenów, założona przez biskupa 
stuła symbolizuje miłość, a ornat czyny sprawiedliwości, po święceniach następuje koncelebra z udzielającym święcenia biskupem.

Po tych dwóch referatach wywiązała się dyskusja: ks. Walerian Bugiel (Republika Czeska) zauważył różnicę między nałożeniem rąk a wyciągnięciem rąk, abp Damian Zimoń naświetlił liturgię święceń jako przestrzeń wiary Kościoła, ks. Jarosław Superson SAC pytał o dzień udzielania święceń: sobota czy niedziela, ks. Czesław Krakowiak proponował, aby używać raczej terminu święcenia niż ordynacja.

Następnie uczestnicy udali się do Biblioteki Śląskiej, aby zobaczyć przechowywane tam księgi liturgiczne, a potem celebrowali Eucharystię i liturgię godzin w kościele katedralnym Chrystusa Króla pod przewodnictwem abpa Damiana Zimonia. Na zakończenie mszy świętej wręczono arcybiskupowi dedykowaną mu księgę jubileuszową z racji 25. rocznicy sakry biskupiej. Mszę świętą koncelebrował także z liturgistami bp Stefan Cichy, przewodniczący Komisji ds. Kultu Bożego i Dyscypliny Sakramentów Konferencji Episkopatu Polski.

Sesję przedpołudniową 8 września 2010 roku prowadziła s. dr hab. Adelajda Sielepin CHR (Uniwersytet Papieski Jana Pawła II). Pierwszym referentem drugiego dnia sympozjum był ks. dr Waldemar Pałęcki (Katolicki Uniwersytet Lubelski Jana Pawła II), który przedstawił Ordinatio presbyterorum w Pontificale Romanum z 1596 roku. Prelegent zaznaczył, że pontyfikał z 1596 roku zredagowano na podstawie wcześniejszych liturgicznych ksiąg używanych w Rzymie. Obrzęd święceń prezbiteratu obejmował: przyjęcie kandydata do święceń przez biskupa, przedstawienie kandydatów z imienia, dialog między archidiakonem a biskupem, przemowę biskupa, obrzędy sakramentalne, obrzędy wyjaśniające, koncelebrację mszalną z biskupem, przekazanie znaku pokoju, udzielenie prezbiterom komunii świętej tylko pod postacią chleba, przyjęcie od kandydatów wyznania wiary, przekazanie im władzy odpuszczenia grzechów, złożenie przez nich przysięgi wierności, napomnienie biskupa, że neoprezbiterzy mają się uczyć od starszych kapłanów konsekrowania, łamania i udzielenia komunii świętej, błogosławieństwo biskupa, błogosławieństwo końcowe biskupa, ostatnią Ewangelię.

Kolejnym prelegentem był ks. prof. dr hab. Bogusław Nadolski TChr, który przedstawił Święcenia absolutne, święcenia zakonników. W początkach Kościoła udzielano święceń prezbiterowi dla konkretnej wspólnoty. Od czasów karolińskich przypadki ordynacji bez konkretnego przydziału były coraz częstsze, a od XII wieku stały się powszechne. Papieże uważali święcenia bez konkretnej wspólnoty za ważne, ale biskup miał zapewnić finansowe utrzymanie takiego duchownego. Święcenia bez przydziału do wspólnoty spowodowały zmiany w dziedzinie liturgii: przejście od mszy wspólnotowej do mszy prywatnej, od pokuty kanonicznej do taryfikowanej i indywidualnej, od ministra posługi dla wspólnoty do stanu kapłańskiego. Także w tym czasie podkreślano, że Eucharystia jest opus bonum i dlatego powinna być odprawiana jak najczęściej, stąd pojawiły się binacje, msze święte prywatne w klasztorach, a wraz z tym rozkwit intencji. Coraz częstsze święcenia mnichów na prezbiterów, a następnie powstanie i rozwój uniwersytetów wpłynęły na powstanie święceń absolutnych. Liczba ołtarzy w kościołach zwiększała się, powstała księga Missale Plenum, następowała zmiana porządku dnia w klasztorach.

Po tych dwóch referatach miała miejsce dyskusja. Ks. Walerian Bugiel zauważył, że Wschód podkreśla jedność: wspólnota gromadzi się w konkretnym dniu przy jed- 
nym ołtarzu, nie ma święceń absolutnych, istnieje ścisła i konkretna praktyka postna. Ks. prof. dr hab. Jan Janicki (Uniwersytet Papieski Jana Pawła II) przypomniał, że magisterium Soboru Trydenckiego nie obłożyło anatemą mszy świętych prywatnych. Ks. prof. dr hab. Jacek Nowak (Uniwersytet Kardynała Stefana Wyszyńskiego) pytał, czy panujący na przełomie tysiącleci feudalizm nie wpłynął na ówczesną duchowość teologię. Ks. Stanisław Hołodok (Białystok) zauważył, że prawosławni stawiają ołtarz drewniany w kościele, w którym tego samego dnia wcześniej sprawowano już Eucharystię. S. Adelajda Sielepin (Uniwersytet Papieski Jana Pawła II) zaznaczyła, że w tych historycznych czasach często podkreślano liczbę odprawionych mszy świętych i wyrecytowanych modlitw, ale pomimo tak numerycznego traktowania liturgii i modlitw przecież wyrażały one wiarę i pobożność. Ks. Józef Górzyński (Warszawa) przedstawił praktykę księży studentów w Rzymie, którzy uczestniczą we mszy świętej, ale jej nie sprawują, nie koncelebrują. Ustosunkowując się do tych słów, ks. Bogusław Nadolski przypomniał, że do VIII wieku nie sprawowano Eucharystii codziennie. Powstałe później praktyki przejęły pewne elementy z życia świeckiego.

Ks. prof. dr hab. Jan Janicki (Uniwersytet Papieski Jana Pawła II) wygłosił piąty referat Prezbiter i przewodniczenie Eucharystii do Soboru Trydenckiego. Zauważył, że w swojej historii Kościół wypracował posługi czasowe (funkcje) i ministerium (posługę). W antycznym Kościele posługę pełnili biskupi i prezbiterzy, którzy sprawowali „obrzęd łamania chleba". Ze świadectw wynika, że terminy biskup i prezbiter były synonimami. Następnie wykładowca zanalizował: Listy Ignacego Antiocheńskiego, Apologie Justyna i Tradycje Apostolską Hipolita, wskazując w nich elementy przypisane przewodniczącemu zgromadzenia, którego postać zaczęła się wyróżniać od momentu używania specjalnych szat.

Ks. dr hab. Przemysław Nowakowski (Uniwersytet Papieski Jana Pawła II) przedstawił Święcenia prezbiterów $w$ Kościele prawosławnym. Zanalizował przebieg obrządku bizantyjsko-słowiańskiego, w którym po dziś dzień są święcenia niższe (minister kościelny) i wyższe (ministrowie wyświęceni), oba z gestem nałożenia rąk. Świecenia wyższe przyjmuje kandydat pojedynczo w prezbiterium, natomiast niższe są udzielane poza nim także wielu kandydatom. Sam obrzęd święceń ukształtował się w XVII wieku. Zawiera: obrzędy wstępne, obrzędy sakramentalne, obrzędy wyjaśniające, dołączenie neoprezbitera do koncelebry, komunię świętą. Po otrzymanych święceniach neoprezbiter przez 7 dni sprawuje mszę świętą, aby otrzymać 7 darów Ducha Świętego. Prezbiter jest nazywany ojcem, gdyż sprawując sakramenty, odradza na nowo wiernych.

Po tych dwóch referatach nastąpiła dyskusja. Ks. Wincenty Bugiel podkreślił, że Wschód dla wszystkich święceń używa tych samych modlitw, natomiast z powodu wielości epiklez modlitwa sakramentalna jest trudna do zlokalizowania. Ks. Czesław Krakowiak pytał, kiedy i dlaczego nastąpiło przejście od przewodniczenia Eucharystii przez biskupa do przewodniczenia prezbiterów. Na co ks. Jan Janicki zauważył, że powstające chrześcijańskie wspólnoty (etap wolności Kościoła) wytworzyły tę praktykę, co spowodowało oddzielenie się biskupa od prezbitera. Ks. Bogusław Nadolski opowiedział się za dwoma grupami posługujących: misjonarze wędrowni i prezbiterzy, a na misjach episkopoi. Ks. Czesław Krakowiak podał konkretną bibliografię dotyczącą kapłaństwa starożytnego, wypracowaną przez ks. prof. Stanisława Longosza (Katolicki Uniwersytet Lubelski Jana Pawła II): „Vox Patrum” 13-15 (1993-1995), jak również 
rocznik 2008. Po krótkiej polemice na temat źródeł ks. Andrzej Żądło zaproponował, aby nie zatrzymywać się na obecnym etapie dyskusji i wniosków, ale podjąć zagadnienie w przyszłości, dopełniając obraz tematem współczesnej duchowości prezbiterów.

Po obiedzie liturgiści udali się do sanktuarium Matki Bożej Piekarskiej w Piekarach Śląskich, a następnie do kościołów Ducha Świętego i bł. Karoliny w Tychach.

Ostatni dzień sympozjum prowadził ks. dr hab. Stanisław Araszczuk, prorektor Papieskiego Wydziału Teologicznego we Wrocławiu. Bp Stefan Cichy przedstawił relację z prac Komisji Liturgicznej Episkopatu Polski. Poinformował, że na konferencji w Łomży w 2009 roku zatwierdzono Obrzęd Błogosławieństwa Wdów (jest to pierwsza próba takiego opracowania, która czeka na zatwierdzenie Kongregacji); Obrzędy pogrzebu związane z kremacją (aneks do istniejących obrzędów pogrzebowych); Modlitwę za Żydów i Obrzędy Wielkiego Piątku. Z kolei na konferencji w Olsztynie został przyjęty Ceremoniał liturgicznej postugi biskupów, który po zatwierdzeniu ma być drukowany, wystąpiono też do Kongregacji ds. Kultu Bożego i Dyscypliny Sakramnetów z prośbą o włączenie św. Faustyny do kalendarza ogólnego Kościoła, a św. Z. Felińskiego, bł. J. Popiełuszkę i M. Sopoćkę do kalendarza ogólnopolskiego. Natomiast trwają prace nad obrzędami Triduum Paschalnego, tłumaczeniem mszału, Martyrologium Romanum, lekcjonarzem, obrzędami posług lektorów i akolitów oraz nadzwyczajnych szafarzy, obrzędem profesji zakonnej.

Następnie sprawozdania z katedr i instytutów przedstawili: ks. dr hab. Andrzej Żądło (prof. Uniwersytetu Śląskiego), ks. dr hab. Przemysław Nowakowski (Uniwersytet Papieski Jana Pawła II), ks. prof. dr hab. Helmut Sobeczko (Uniwersytet Opolski), ks dr Dominik Ostrowski (Papieski Wydział Teologiczny we Wrocławiu), ks. prof. dr hab. Kazimierz Matwiejuk (Uniwersytet Kardynała Stefana Wyszyńskiego), ks. prof. dr hab. Zbigniew Wit (Katolicki Uniwersytet Lubelski Jana Pawła II), ks. dr hab. Kazimierz Lijka (Uniwersytet im. Adama Mickiewicza), ks. dr Daniel Brzeziński (Toruń), ks. dr Zbigniew Kobus (Szczecin). Poinformowano także o rozpoczęciu prac nad procesem beatyfikacyjnym ks. Wojciecha Danielskiego w 25. rocznicę śmierci i ks. Wincentego Granata. Ks. dr Stanisław Szczepaniec (Uniwersytet Papieski Jana Pawła II) zaprezentował pola pracy Podkomisji ds. Duszpasterstwa Służby Liturgicznej. Zostało już opracowane i opublikowane Dyrektorium Duszpasterskie Służby Liturgicznej, a trwają prace nad przygotowaniem pomocy do formacji lektorów i akolitów.

Jako temat przyszłorocznego sympozjum, które odbędzie się na Górze Św. Anny w dniach 6-8 września 2011, wybrano zagadnienie Pogrzeb chrześcijański - obrzędy, teologia, praktyka.

Kraków

ADELAJDA SIELEPIN CHR, JAROSŁAW A. SUPERSON SAC 